\title{
Performance of broiler chickens supplemented with Mexican oregano oil (Lippia berlandieri Schauer)
}

\section{Ramón Silva Vázquez¹, Lorenzo Antonio Durán Meléndez¹, Eduardo Santellano Estrada1, Carlos Rodríguez Muela', Guillermo Villalobos Villalobos' ${ }^{1}$, Gerardo Méndez Zamora' Michael E. Hume ${ }^{2}$}

\footnotetext{
${ }^{1}$ Universidad Autónoma de Chihuahua, Facultad de Zootecnia y Ecología, Chihuahua, Chihuahua, México.

${ }^{2}$ Food and Feed Safety Research Unit, U.S. Department of Agriculture, Texas, USA.
}

ABSTRACT - The objective of this research was to evaluate the inclusion of two qualities of Mexican oregano oil (MOO) in broiler diets on broiler weight, feed intake, feed efficiency, average daily gain, and water intake. The qualities were $\mathrm{MOO}_{1}$ (4\% thymol, $60 \%$ carvacrol) and $\mathrm{MOO}_{2}(40 \%$ thymol, $20 \%$ carvacrol). Nine treatments were prepared by the combinations of $\mathrm{MOO}_{1}+\mathrm{MOO}_{2}(0,400$, and $800 \mathrm{mg} \mathrm{kg}$; added per kg of feed) respectively: $0+0,0+400,0+800,400+0,400+400,400+800$, $800+0,800+400$, and $800+800$. Eighteen chicks per treatment were divided in a completely randomized design into nine cages. Broiler weights were altered by the treatments at $21 \mathrm{~d}$, when $400+400$ had the highest weight, and on day 39 , when the greatest weight was seen in broilers on treatments $800+0$ and $800+400$. Feed intake was affected by treatment on day 39 , with broilers on $800+0$ exhibiting the highest values. Water intake was influenced by the treatments on days $14,21,35$, and 39 , when $0+0$ represented the lowest. Feed efficiency was altered by the treatments on days 14, 28, 35, and 39, whereas average daily gain was affected from days 14 to 39. Supplementation of Mexican oregano oil has beneficial effects on broiler weight, feed efficiency, average daily gain, and feed and water intakes. Combinations of thymol and carvacrol levels have varying effects on these parameters. The higher relative body weights of groups $400+0,800+0$, and $800+400$ suggest positive market value effects of these combinations of Mexican oregano oil.

Key Words: carvacrol, extract, inclusion, thymol, water intake

\section{Introduction}

Antibiotics have been used as growth promoters and for disease prevention in poultry production. However, antibiotic residues have been found in poultry meat, and these residues are considered risks to human health (Castanon, 2007). Therefore, researchers are investigating natural alternatives to antibiotics to improve poultry production, e.g., oregano essential oil (OEO) (Adil et al., 2011; Khan et al., 2012). This oil is a mixture of several components, mainly the monoterpenes thymol and carvacrol (Kintzios, 2002), and is considered GRAS (Generally Recognized as Safe) by the United States Food and Drug Administration (Silva and Dunford, 2005). The chemical makeup of OEO depends on the OEO quality and is related to the phenological stage of the plant (Dunford and Silva, 2005).

Received March 21, 2015 and accepted May 28, 2015

Corresponding author: rsilva63@yahoo.com

http://dx.doi.org/10.1590/S1806-92902015000800003

Copyright $@ 2015$ Sociedade Brasileira de Zootecnia. This is an Open Access article distributed under the terms of the Creative Commons Attribution Non-Commercial License, which permits unrestricted non-commercial use, distribution, and reproduction in any medium, provided the original work is properly cited.
Oregano essential oil, as a natural alternative to antibiotics, has potentially desirable production properties and stimulatory effects on poultry digestion (Alçiçek et al., 2004; Zhang et al., 2005). These features can improve the feed efficiency because of positive effects on the nutrient digestibility (Jamroz et al., 2003; Hernandez et al., 2004) and antimicrobial activities (Dorman and Deans, 2000). Oregano essential oil from Origanum vulgare L. in broiler diets has been shown in several studies to improve body weight and feed intake; however, the OEO efficacy on broiler performance remains controversial (Symeon et al., 2010).

On the other hand, little attention has been afforded to the use of Mexican oregano oil (MOO) harvested from Lippia berlandieri Schauer in broiler production. This plant is used as a food seasoning, as well as against respiratory and digestive diseases (Rivero-Cruz et al., 2011). Mexican oregano oil is characterized by a strong odor and its various biological activities, attributed to the high content of phenolic components carvacrol and thymol (Arcila-Lozano et al., 2004; Avila-Sosa et al., 2010). These components exhibit antibacterial, antioxidant, antiviral, anti-fungal, and insecticide activities (Silva and Dunford, 2005; OrtegaNieblas et al., 2011). Recently, OEO was investigated in 
the production of chickens and turkeys (Gopi et al., 2013; Giannenas et al., 2014; Kirkpinar et al., 2014).

The hypothesis was that bioactive components of MOO may work as growth promoters in broiler production. The aim of the current study was to evaluate MOO supplementation on broiler weight, feed intake, feed efficiency, average daily gain, and water intake.

\section{Material and Methods}

All procedures used in this study were approved by Facultad de Zootecnia y Ecologia in the Universidad Autonoma de Chihuahua, Chihuahua, Mexico, and Laboratory Animal Care Committee. The animals used in this study were managed according to the guidelines recommended by the Mexican animal welfare standards (NOM-062-ZOO-1999).

The study was conducted in Chihuahua, Mexico. This city is located between the $28^{\circ} 38^{\prime} \mathrm{N}$ and $106^{\circ} 04^{\prime} \mathrm{W}$ parallels at an altitude of $1,440 \mathrm{~m}$, with a mean annual temperature $18{ }^{\circ} \mathrm{C}$, annual precipitation between $200-600 \mathrm{~mm}$, and is in a tempered dry climate (INEGI, 2013).

A total of 162 one-day-old broiler chickens of commercial genetic line Ross were used in this study. Water and feed were provided ad libitum. Husbandry practices were as described by Roofchaee et al. (2011). The temperature was set at $34{ }^{\circ} \mathrm{C}$ on the first day, followed by $32{ }^{\circ} \mathrm{C}$ over the remainder of the first week, and then it was reduced gradually by $3{ }^{\circ} \mathrm{C}$ per week until it reached $23{ }^{\circ} \mathrm{C}$. The relative humidity fluctuated between 25 and $75 \%$. Lighting was provided $22 \mathrm{~h} \mathrm{~d}^{-1}$. The diet supplied (ingredients expressed on a dry matter basis) was an isoenergetic and isoproteic formulation (NRC, 1994) of poultry broiler starter diet to 21 days and finisher diet supplied for the remaining 18 days, in a total of 39 days (Table 1). It is important to stress that during the sixth week (35 to 39 days), the chicks were fed for four days and this could cause some confusions about body weight, feed intake, water intake, feed efficiency, and weight gain, which showed an abrupt change (Tables 3 and 6).

An arrangement of treatments was used by combining two variations of the Mexican oregano oil. The first Mexican oregano oil $\left(\mathrm{MOO}_{1}\right)$ contained $4 \%$ thymol and $60 \%$ carvacrol, while the second oil tested $\left(\mathrm{MOO}_{2}\right)$ consisted of $40 \%$ thymol and $20 \%$ carvacrol (the major components of MOO are presented in Table 2). Therefore, nine treatments were prepared by the combinations of $\mathrm{MOO}_{1}+\mathrm{MOO}_{2}$ $\left(0,400\right.$, and $800 \mathrm{mg} \mathrm{kg}^{-1}$; added per $\mathrm{kg}$ of feed) respectively: $0+0,0+400,0+800,400+0,400+400,400+800,800+0$, $800+400$, and $800+800$. Each treatment consisted of 18 broilers distributed into nine cages $(30 \times 33 \times 44 \mathrm{~cm})$ with two chicks per cage. The MOO were purchased from Natural Solutions Company SMI (Jimenez, Chihuahua, Mexico) and were prepared by steam distillation of two cultivars of Lippia berlandieri Schauer. The oregano oil treatments were added to the canola oil as carrier and mixed slowly with the basal diets for $10 \mathrm{~min}$.

The initial weight (IW, g) of each chick was determined at the beginning of the experiment. The studied variables were body weight (BW, g), feed intake (FI, g), and water

Table 1 - Ingredients of the experimental starter and finisher diets for broilers

\begin{tabular}{lcc}
\hline & \multicolumn{2}{c}{ Diet $^{2}$} \\
\cline { 2 - 3 } Ingredients $\left(\mathrm{g} \mathrm{kg}^{-1}\right)^{1}$ & $\begin{array}{c}\text { Starter } \\
(0 \text { to } 21 \text { days })\end{array}$ & $\begin{array}{c}\text { Finisher } \\
(22 \text { to } 39 \text { days })\end{array}$ \\
\hline Corn & 467.2 & 556.4 \\
Soybean $(48 \% \mathrm{CP})$ & 392.2 & 312.9 \\
Corn gluten & 53.3 & 44.4 \\
Vitamin and mineral premix & 11.7 & 13.3 \\
Calcium carbonate & 14.4 & 21.4 \\
Dicalcium phosphate & 21.3 & 22.2 \\
Sodium chloride & 6.0 & 6.4 \\
DL-methionine & 1.9 & 0.8 \\
Canola oil ${ }^{\circledR 4}$ & 32.0 & 22.2 \\
Total & $1,000.0$ & $1,000.0$ \\
Calculated contents & & \\
Metabolizable energy $(\mathrm{kcal} \mathrm{kg})^{-1}$ & $3,200.0$ & $3,200.0$ \\
Crude protein $(\%)$ & 23.0 & 19.0 \\
Lysine $(\%)$ & 1.1 & 0.9 \\
Methionine + cystine $(\%)$ & 0.9 & 0.62 \\
Calcium $(\%)$ & 1.0 & 0.8 \\
Available phosphorus $(\%)$ & 0.5 & 0.3 \\
\hline
\end{tabular}

${ }^{1}$ Ingredients were incorporated per $\mathrm{kg}$ of the experimental diet (expressed on a dry matter basis).

${ }^{2}$ Diets were formulated according to the nutrient requirements for broilers as recommended by NRC (1994)

${ }^{3}$ Every $10 \mathrm{~g}$ of premix consisted of $24.0 \mathrm{mg}$ of vitamin $\mathrm{A}\left(500,000 \mathrm{IU} \mathrm{g}^{-1}\right) ; 6.0 \mathrm{mg}$ of vitamin D3 (100,000 IU g $\left.{ }^{-1}\right) ; 60.0 \mathrm{mg}$ of vitamin E (500 IU g $\left.{ }^{-1}\right) ; 6.6 \mathrm{mg}$ of vitamin $\mathrm{K} 3$ (purity, 22.7\%); $100.0 \mathrm{mg}$ of vitamin B12 (purity, 0.1\%); 2,000.0 $\mathrm{mg}$ of biotin (purity, $0.01 \%$ ); $1,100.0 \mathrm{mg}$ of choline chloride (purity, 50\%); $1.1 \mathrm{mg}$ of folic acid (purity, 90\%); $65.2 \mathrm{mg}$ of nicotinic acid (purity, 100\%); $16.3 \mathrm{mg}$ of d-pantothenate (purity, 92\%); $4.5 \mathrm{mg}$ of vitamin B6 (purity, 100\%); $12.5 \mathrm{mg}$ of riboflavin (purity, $80 \%$ ); $2.5 \mathrm{mg}$ of vitamin $\mathrm{B} 1$ (purity, $100 \%$ ); $32.00 \mathrm{mg}$ of $\mathrm{CuSO} 5 \mathrm{H}_{2} \mathrm{O} ; 333.20$ $\mathrm{mg}$ of $\mathrm{FeSO}_{4} \mathrm{H}_{2} \mathrm{O} ; 166.80 \mathrm{mg}$ of $\mathrm{MnO} ; 1.0 \mathrm{mg}$ of $\mathrm{Na}_{2} \mathrm{SeO}_{3} 5 \mathrm{H}_{2} \mathrm{O} ; 220.00 \mathrm{mg}$ of $\mathrm{ZnSO}_{4} \mathrm{H}_{2} \mathrm{O} ; 4.80 \mathrm{mg}$ of $\mathrm{CoSO}_{4} 7 \mathrm{H}_{2} \mathrm{O} ; 0.56 \mathrm{mg}$ of $\mathrm{KI} ; 100.00 \mathrm{mg}$ of ethoxyquin, and $5,742.94 \mathrm{mg}$ of corn meal as carrier.

${ }^{4}$ Canola oil was purchased from the company Industrial Patrona, S.A. de C.V.

${ }^{5}$ Calculated contents according to typical values for broilers fed well-balanced diets providing 3,200 kcal ME/kg (Table 2-5, page 26; NRC, 1994)

Table 2 - Main components of the Mexican oregano oil

\begin{tabular}{lcc}
\hline \multirow{2}{*}{ Component $^{1}$} & \multicolumn{2}{c}{ Concentration (\%) } \\
\cline { 2 - 3 } & $\mathrm{MOO}_{1}$ & $\mathrm{MOO}_{2}$ \\
\hline Carvacrol & 60.02 & 20.06 \\
Thymol & 3.96 & 40.08 \\
Cineole 1,8 & 23.63 & 15.31 \\
P-cymene & 9.57 & 16.03 \\
Gamma-terpinene & 0.11 & 4.72 \\
Others & 2.71 & 3.80 \\
\hline
\end{tabular}

${ }^{1}$ Mexican oregano oil (MOO) components were analyzed by GC/MS Clarus SQ 8 $\left(\right.$ PerkinElmer $^{\circledR}$ ). 
intake (WI, mL) at $0,7,14,21,28$, and 39 days, during the fattening period. These measurements were used to estimate the average daily gain [ADG; (currentBW - previousBW/ days)] and feed efficiency (FE; BW/FI) as weight gain/feed intake. The obtained data were analyzed with the GLM procedure of SAS (Statistical Analysis System, version 9), using the following statistical model: $\mathrm{y}_{i j k}=\mu+\mathrm{T}_{i}+\delta_{j}+$ $(\mathrm{T} \delta)_{i j}+\Phi_{k(i j)}+\lambda+\varepsilon_{i j k}$, in which $\mathrm{y}_{i j k}=$ variables BW, FI, WI, ADG, and FE measured during the experiment over time; $\mu=$ overall mean; $\mathrm{T}_{i}=$ effect of the $i$-th treatment; $\delta_{j}=$ effect of the $j$-th day $(0,7,14,21,28$, and 39 days $)$ during the fattening period; $(\mathrm{T} \delta)_{i j}=$ effect of the interaction between the $i$-th treatment and the $j$-th day; $\Phi_{k(i j)}=$ nested effect of the $i$-th treatment in each cage where the chicken was for the $j$-th day of fattening; $\lambda=$ covariate effect IW; and $\varepsilon_{i j k}=$ random error normally distributed with zero mean and variance $\sigma^{2}\left[\varepsilon_{i j k} \sim \mathrm{N}\left(0, \sigma^{2}\right)\right]$. When the effect of the interaction between treatments and days was significant $(\mathrm{P} \leq 0.05)$, the ESTIMATE statement of SAS (Statistical Analysis System, version 9) was used to compare means with a probability of $5 \%$.

\section{Results and Discussion}

Mexican oregano oil treatments had significant effects $(\mathrm{P} \leq 0.05)$ on the broiler performance variables $\mathrm{BW}$, WI, FE, FI, and ADG. Results obtained in the studies of Basmacioğlu et al. (2004) and Symeon et al. (2009) with OEO differed in the effects found on broiler production variables and did not reveal differences in final weight, whereas Bozkurt et al. (2009) found differences in BW and FC at 42 days and Kirkpınar et al. (2011) obtained only effects on BW at 7, 14, 21, 28, and 42 days, but FI only at 42 days. Brenes and Roura (2010) identified different mechanisms of the OEO actions that were grouped into four categories: sensorial, metabolic, antioxidant, and antimicrobial, in which oronasal sensing prepares the gastrointestinal tract for food reception and stimulates digestive secretions (saliva, salivary amylase, lipase, amylase, and proteases) and gut motility. Those responses could have contributed to results obtained in the performance of broilers supplemented with Mexican oregano oils.

Treatments $400+800$ and $800+0$ had the lowest $(\mathrm{P} \leq 0.05)$ weights on day 7 (Table 3). Treatment $800+0$ provided the lowest $(\mathrm{P} \leq 0.05)$ weight on day 14 , whereas $0+0$ and $800+800$ had the lowest $(\mathrm{P} \leq 0.05)$ weights on day 21 . From days 28 to 39 and 0 to 39 there were no differences $(\mathrm{P}>0.05)$ between treatment groups. However, treatments $800+0$ and $800+400$ resulted in the highest weights at 39 days, with nearly $100 \mathrm{~g}$ more weight than broilers in $0+0$, which may translate into a higher market value. Similarly, other studies using OEO in broilers obtained improvements in performance (Roofchaee et al., 2011; Alali et al., 2013; El-Ghany and Ismail, 2013; Küçükyilmaz et al. 2014). The proposed action of OEO on growth promotion is due to the content of thymol and carvacrol, as these components may stimulate appetite and enhance the activity of digestive enzymes and absorption of nutrients (Cross et al., 2007; Windisch et al., 2008; Roofchaee et al., 2011). In addition, Sugiharto (2014) cited that the mechanisms of action of oregano oils on the grown performance of chickens are improvements in the flavor and palatability of the feed and the potential improvements in feed intake and performance of chickens; stimulation of the proliferation and growth of absorptive cells in the gastrointestinal tract (resulting in greater villus height and deeper crypt); and influences on the production and/or activity of the digestive enzymes, e.g., increased activities of amylase and protease. The improvements in BW in the current study could be attributed to these positive effects of thymol and carvacrol.

Table 3 - Effect of inclusion of the Mexican oregano oil on body weights of broilers from hatch to 39 days of age

\begin{tabular}{|c|c|c|c|c|c|c|}
\hline \multirow{2}{*}{$\begin{array}{l}\text { Treatment } \mathrm{MOO}_{1}+\mathrm{MOO}_{2} \\
\left(\mathrm{mg} \mathrm{kg}{ }^{-1} \text { of feed }\right)\end{array}$} & \multicolumn{6}{|c|}{ Period $(\text { days })^{1}$} \\
\hline & $0-7$ & $7-14$ & $14-21$ & $21-28$ & $28-35$ & $0-39$ \\
\hline $0+0$ & $140.44 \mathrm{ab}$ & $363.61 \mathrm{ab}$ & $724.56 b$ & $1,304.44$ & $1,682.78$ & $1,945.56$ \\
\hline $0+400$ & $139.89 \mathrm{ab}$ & $384.03 \mathrm{ab}$ & $805.72 \mathrm{ab}$ & $1,351.67$ & $1,918.89$ & $2,160.56$ \\
\hline $400+0$ & $146.79 \mathrm{a}$ & $404.61 \mathrm{a}$ & $857.36 \mathrm{a}$ & $1,396.43$ & $1,904.29$ & $2,215.71$ \\
\hline $400+400$ & $139.31 \mathrm{ab}$ & $373.25 \mathrm{ab}$ & $803.11 \mathrm{ab}$ & $1,315.56$ & $1,846.11$ & $2,044.44$ \\
\hline $400+800$ & $131.39 \mathrm{~b}$ & $373.75 \mathrm{ab}$ & 798.33ab & $1,317.22$ & $1,820.00$ & $2,136.67$ \\
\hline $800+800$ & $151.19 \mathrm{a}$ & $385.47 \mathrm{ab}$ & $743.81 \mathrm{~b}$ & $1,313.75$ & $1,777.50$ & $2,071.88$ \\
\hline $\mathrm{SEM}^{2}$ & 1.50 & 5.11 & 11.54 & 20.51 & 20.02 & 35.56 \\
\hline P-value & $<0.01$ & $<0.01$ & $<0.01$ & 0.13 & 0.21 & 0.23 \\
\hline
\end{tabular}

${ }^{1}$ Mean body weights $(\mathrm{g})$ in the same column followed by different letters are significantly different $(\mathrm{P} \leq 0.05)$. Abrupt changes were observed from day 35 to 39 because the chicks were fed for four days.

${ }^{2}$ Pooled standard error of least squares means. 
Feed intake (FI) was affected also by supplementation of MOO (Table 4). On day 14, broilers in 800+400 expressed the greatest FI, whereas the broilers on treatment $0+0$ had the lowest $(\mathrm{P} \leq 0.05) \mathrm{FI}$.

At 21 days, $800+800$ had the lowest FI $(\mathrm{P} \leq 0.05)$ compared with the other treatments. Feed intake was not different $(\mathrm{P}>0.05)$ at $28-35$ and $0-39$ days between treatments, but a difference $(\mathrm{P} \leq 0.05)$ was found at 39 days, when FI was lowest in broilers on treatment $0+0$. In contrast, Lee et al. (2003) indicated that the inclusion of $200 \mathrm{ppm}$ of carvacrol in the diet of chickens can have adverse responses on FI. However, the results of our study contradict this observation, possibly because the dose of MOO was higher. Conversely, the lower FI for $800+800$, especially at days 14 to 35 , with $\mathrm{MOO}$ at the highest concentration $\left(1,600 \mathrm{mg} \mathrm{kg}^{-1}\right)$, may suggest adverse effects due to OEO component toxicity. Dušan et al. (2006) indicated that carvacrol at $55 \%$ can have cytotoxic effects in chickens and therefore a decrease in FI.
At 39 days, $800+0$ recorded the highest relative water intake (WI), which was greater $(\mathrm{P}>0.05)$ than that consumed by $0+0$ and $400+400$, which had the lowest consumption (Table 5). From days 14 to 39, WI was relatively and statically different between the treatments, with the exception of $800+800$ at day 35 , lower for $0+0$ when compared with the treatments that received MOO. Manning et al. (2007) commented that water consumption could be modified by the physiological states of the chicken during growth and development, influenced by breed, sex, population density, room temperature, health, and welfare and food consumption; however, in the current study, the 0-39 day period exhibited no statistical differences between the treatments (Table 5). Our results showed that WI is closely related to FI and the concentration of MOO $(r=0.824$ $\mathrm{P}<0.01)$. The increase of $\mathrm{MOO}$ in the treatments increased WI and FI and, thus, the weights of the chickens.

The feed efficiency (FE) was not affected $(\mathrm{P}>0.05)$ at 7, 21, and 0-39 days (Table 6). However, in the periods of

Table 4 - Influence of Mexican oregano oil on feed intake of broilers from hatch to 39 days of age

\begin{tabular}{|c|c|c|c|c|c|c|c|}
\hline \multirow{2}{*}{$\begin{array}{l}\text { Treatment } \mathrm{MOO}_{1}+\mathrm{MOO}_{2} \\
\left(\mathrm{mg} \mathrm{kg}^{-1} \text { of feed }\right)\end{array}$} & \multicolumn{6}{|c|}{ Period (days) ${ }^{1}$} & \multirow[b]{2}{*}{$0-39^{2}$} \\
\hline & $0-7$ & $7-14$ & $14-21$ & $21-28$ & $28-35$ & $35-39$ & \\
\hline $0+0$ & 105.78 & $269.69 b$ & $526.67 \mathrm{a}$ & 812.94 & $1,049.97$ & $570.33 b$ & $3,335.38$ \\
\hline $0+400$ & 99.82 & $292.67 \mathrm{ab}$ & $558.72 \mathrm{a}$ & 825.36 & 973.92 & $627.14 \mathrm{ab}$ & $3,377.63$ \\
\hline $0+800$ & 108.19 & $291.17 \mathrm{ab}$ & $533.50 \mathrm{a}$ & 799.75 & 974.97 & $652.44 \mathrm{ab}$ & $3,360.02$ \\
\hline $400+0$ & 105.64 & $293.25 \mathrm{ab}$ & $550.04 \mathrm{a}$ & 862.50 & $1,014.86$ & $677.96 \mathrm{ab}$ & $3,504.25$ \\
\hline $400+400$ & 99.78 & $282.67 \mathrm{ab}$ & $548.78 \mathrm{a}$ & 847.14 & 980.72 & $593.19 \mathrm{ab}$ & $3,352.28$ \\
\hline $400+800$ & 94.00 & $286.89 \mathrm{ab}$ & $541.14 \mathrm{a}$ & 849.22 & 974.58 & $664.97 \mathrm{ab}$ & $3,410.81$ \\
\hline $800+0$ & 92.75 & $278.47 \mathrm{ab}$ & $522.34 \mathrm{a}$ & 871.03 & $1,080.65$ & $704.31 \mathrm{a}$ & $3,549.55$ \\
\hline $800+400$ & 95.33 & $302.97 \mathrm{a}$ & $537.08 \mathrm{a}$ & 915.89 & $1,044.86$ & $674.75 \mathrm{ab}$ & $3,570.88$ \\
\hline $800+800$ & 108.81 & $293.38 \mathrm{ab}$ & $451.84 b$ & 806.88 & 957.09 & $617.44 \mathrm{ab}$ & $3,235.44$ \\
\hline $\mathrm{SEM}^{3}$ & 1.19 & 3.27 & 6.69 & 13.61 & 22.84 & 13.16 & 142.29 \\
\hline P-value & 0.10 & $<0.01$ & $<0.01$ & 0.20 & 0.95 & $<0.01$ & 0.79 \\
\hline
\end{tabular}

${ }^{1}$ Mean feed intake values $(\mathrm{g})$ in the same column followed by different letters are significantly different $(\mathrm{P}<0.05)$. Abrupt changes were observed from day 35 to 39 because the chicks were fed for four days.

${ }^{2}$ Recorded consumption from day 0 to 39

${ }^{3}$ Pooled standard error of least squares means.

Table 5 - Influence of Mexican oregano oil on water intake of broilers from hatch to 39 days of age

\begin{tabular}{|c|c|c|c|c|c|c|c|}
\hline \multirow{2}{*}{$\begin{array}{l}\text { Treatment } \mathrm{MOO}_{1}+\mathrm{MOO}_{2} \\
\left(\mathrm{mg} \mathrm{kg}^{-1} \text { of feed }\right)\end{array}$} & \multicolumn{6}{|c|}{ Period (days) ${ }^{1}$} & \multirow[b]{2}{*}{$0-39^{2}$} \\
\hline & $0-7$ & $7-14$ & $14-21$ & $21-28$ & $28-35$ & $35-39$ & \\
\hline $0+0$ & 479.19 & $718.56 \mathrm{ab}$ & $1,027.94 b$ & $1,871.08$ & $1,998.03 \mathrm{c}$ & $1,183.39 b$ & $7,278.19$ \\
\hline $0+400$ & 469.94 & $760.78 \mathrm{ab}$ & $1,106.42 \mathrm{ab}$ & $1,978.19$ & $2,265.31 \mathrm{abc}$ & $1,377.33 \mathrm{ab}$ & $7,957.97$ \\
\hline $0+800$ & 480.89 & $726.00 \mathrm{ab}$ & $1,087.25 \mathrm{ab}$ & $1,935.44$ & $2,152.22 \mathrm{abc}$ & $1,471.67 \mathrm{ab}$ & $7,853.47$ \\
\hline $400+0$ & 501.46 & $766.61 \mathrm{ab}$ & $1,133.75 \mathrm{ab}$ & $1,945.57$ & $2,228.75 \mathrm{abc}$ & $1,305.07 \mathrm{ab}$ & $7,881.21$ \\
\hline $400+400$ & 479.44 & $686.08 b$ & $1,108.17 \mathrm{ab}$ & $1,982.33$ & $2,298.39 \mathrm{abc}$ & $1,270.83 b$ & $7,825.24$ \\
\hline $400+800$ & 496.00 & $754.67 \mathrm{ab}$ & $1,096.03 \mathrm{ab}$ & $1,946.36$ & $2,391.14 \mathrm{abc}$ & $1,430.00 \mathrm{ab}$ & $8,114.20$ \\
\hline $800+0$ & 467.25 & $785.81 \mathrm{ab}$ & $1,108.47 \mathrm{ab}$ & $2,058.16$ & $2,642.19 \mathrm{a}$ & $1,687.19 \mathrm{a}$ & $8,749.07$ \\
\hline $800+400$ & 475.58 & $804.92 \mathrm{a}$ & $1,104.75 \mathrm{ab}$ & $1,986.19$ & $2,437.42 \mathrm{abc}$ & $1,522.78 \mathrm{ab}$ & $8,331.64$ \\
\hline $800+800$ & 472.88 & $789.84 \mathrm{ab}$ & $1,180.59 \mathrm{a}$ & $2,019.28$ & $1,998.75 \mathrm{c}$ & $1,321.25 \mathrm{ab}$ & $7,782.59$ \\
\hline $\mathrm{SEM}^{3}$ & 6.27 & 11.51 & 11.03 & 26.81 & 40.76 & 39.77 & 314.07 \\
\hline P-value & 0.21 & $<0.01$ & $<0.01$ & 0.81 & $<0.05$ & $<0.01$ & 0.12 \\
\hline
\end{tabular}

${ }^{1}$ Mean values for water intake $(\mathrm{mL})$ in the same column followed by different letters are different $(\mathrm{P} \leq 0.05)$. Abrupt changes were observed from day 35 to 39 because the chicks were fed for four days.

${ }^{2}$ Recorded consumption from day 0 to 39

${ }^{3}$ Pooled standard error of least squares means. 
$14,28,35$ and 39 days, FE was different $(\mathrm{P} \leq 0.05)$. At 14 days, $400+0$ and $800+800$ had the best FE and $800+0$ had the lowest. At day 28 , the best FE was obtained by $0+800$, while $800+400$ was the least efficient, but at 35 and 39 days $0+0,0+400$, and 400+400 achieved the most efficient FE.

Kirkpinar et al. (2011) saw similar improvements in broiler FE. Supplementation of 150 and $300 \mathrm{ppm}$ of oregano essential oil in the diet improved the performance of the chickens, because of the growth-promoting effect of the oil levels in the diet and the age of the chickens. In our study, the improvement in FE can be attributed to the levels of MOO used. These results agreed partially with those of Cho et al. (2014), who reported no significance at 0-21 d in $\mathrm{BW}$, but at $35 \mathrm{~d}$ found substantially improved FE with the addition of the phytogenic additives thyme and anise star compared with a commercial antibiotic and the control.

Conflicting results were found in other studies (Botsoglou et al., 2002; Basmacioğlu et al., 2004; Cross et al., 2007), which reported that supplementation of 100 , 150 , and 1,000 ppm of OEO in chicken diets did not have an effect on their production performance, while Symeon et al. (2010) concluded that the supplementation of broiler feed with oregano essential oil had significant negative effects on the feeding and drinking behavior as well as on the activity of these broilers. In addition, Cross et al. (2007) reported that phenolic terpenes give a flavor to the diet and it can be unpleasant to chickens during the first weeks. This observation could explain why $0+0$, $0+400$, and $400+400$, with the absence or lower levels of carvacrol, presented the best FE, and these doses may not affect the taste of diets as much as higher levels, and could be accepted by chickens. However, this observation does not explain the results for $400+0$ and the corresponding increase in carvacrol levels.

Some authors have pointed out that herbs, plant extracts, essential oils, and their components (carvacrol, thymol) do not affect ADG (Demir et al., 2003; Bampidis et al., 2005; Cross et al., 2007; Najafi and Torki, 2010); in this case the 0-39 range had no significant statistical difference between treatments, but $0+0$ was lower, while $800+0$ was greater.

Table 6 - Effect of Mexican oregano oil on feed efficiency of broilers from hatch to 39 days of age

\begin{tabular}{|c|c|c|c|c|c|c|c|}
\hline \multirow{2}{*}{$\begin{array}{l}\text { Treatment } \mathrm{MOO}_{1}+\mathrm{MOO}_{2} \\
\left(\mathrm{mg} \mathrm{kg}{ }^{-1} \text { of feed }\right)\end{array}$} & \multicolumn{6}{|c|}{ Period (days) ${ }^{1}$} & \multirow[b]{2}{*}{$0-39$} \\
\hline & $0-7$ & $7-14$ & $14-21$ & $21-28$ & $28-35$ & $35-39$ & \\
\hline $0+0$ & 0.76 & $0.75 \mathrm{ab}$ & 0.74 & $0.65 \mathrm{ab}$ & $0.57 \mathrm{a}$ & $0.29 b$ & 0.59 \\
\hline $0+400$ & 0.71 & $0.76 \mathrm{ab}$ & 0.69 & $0.62 b$ & $0.51 \mathrm{~b}$ & $0.29 b$ & 0.64 \\
\hline $400+0$ & 0.72 & $0.73 b$ & 0.65 & $0.62 b$ & $0.54 \mathrm{ab}$ & $0.31 \mathrm{ab}$ & 0.63 \\
\hline $400+400$ & 0.71 & $0.76 \mathrm{ab}$ & 0.69 & $0.64 \mathrm{ab}$ & $0.53 \mathrm{ab}$ & $0.29 b$ & 0.61 \\
\hline $400+800$ & 0.71 & $0.77 \mathrm{ab}$ & 0.68 & $0.65 \mathrm{ab}$ & $0.53 \mathrm{ab}$ & $0.31 \mathrm{ab}$ & 0.62 \\
\hline $800+800$ & 0.72 & $0.74 b$ & 0.67 & $0.62 b$ & $0.54 \mathrm{ab}$ & $0.34 \mathrm{a}$ & 0.63 \\
\hline SEM $^{2}$ & 0.01 & 0.01 & 0.01 & 0.01 & 0.01 & 0.003 & 0.02 \\
\hline P-value & 0.89 & $<0.05$ & 0.25 & $<0.05$ & $<0.05$ & $<0.05$ & 0.33 \\
\hline
\end{tabular}

${ }^{1}$ Mean values for feed efficiency (body weight $(\mathrm{g}) /$ feed intake $\left.(\mathrm{g})\right)$ in the same column followed by different letters are significantly different $(\mathrm{P} \leq 0.05)$. Abrupt changes were observed from day 35 to 39 because the chicks were fed for four days.

${ }^{2}$ Pooled standard error of least squares means.

Table 7 - Effect of Mexican oregano oil on weight gain of broilers from hatch to 39 days of age

\begin{tabular}{|c|c|c|c|c|c|c|c|}
\hline \multirow{2}{*}{$\begin{array}{l}\text { Treatment } \mathrm{MOO}_{1}+\mathrm{MOO}_{2} \\
\left(\mathrm{mg} \mathrm{kg}^{-1} \text { of feed }\right)\end{array}$} & \multicolumn{6}{|c|}{ Period (days) ${ }^{1}$} & \multirow[b]{2}{*}{$0-39$} \\
\hline & $0-7$ & $7-14$ & $14-21$ & $21-28$ & $28-35$ & $35-39$ & \\
\hline $0+0$ & 15.02 & $26.84 \mathrm{ab}$ & $46.52 \mathrm{abc}$ & $77.80 \mathrm{ab}$ & $49.01 \mathrm{ab}$ & $45.50 \mathrm{ab}$ & 48.98 \\
\hline $0+400$ & 14.94 & $29.83 \mathrm{ab}$ & $55.20 \mathrm{~b}$ & $72.95 \mathrm{a}$ & $75.99 \mathrm{a}$ & $41.27 \mathrm{a}$ & 54.49 \\
\hline $0+800$ & 15.34 & $29.67 \mathrm{ab}$ & $50.73 \mathrm{abc}$ & $69.09 \mathrm{ab}$ & $68.93 \mathrm{ab}$ & $62.61 \mathrm{ab}$ & 54.50 \\
\hline $400+0$ & 15.92 & $31.79 \mathrm{a}$ & $59.64 \mathrm{a}$ & $71.97 \mathrm{a}$ & $67.51 \mathrm{a}$ & $55.22 \mathrm{a}$ & 55.90 \\
\hline $400+400$ & 14.85 & $28.38 \mathrm{ab}$ & $56.37 \mathrm{abc}$ & $68.16 \mathrm{ab}$ & $70.75 \mathrm{ab}$ & $32.61 \mathrm{ab}$ & 51.51 \\
\hline $400+800$ & 13.72 & $29.58 \mathrm{ab}$ & $55.61 \mathrm{abc}$ & $69.08 \mathrm{ab}$ & $66.78 \mathrm{ab}$ & $56.27 \mathrm{ab}$ & 53.88 \\
\hline $800+0$ & 13.29 & $26.78 \mathrm{~b}$ & $55.35 \mathrm{abc}$ & $74.40 \mathrm{a}$ & $84.69 \mathrm{a}$ & $50.31 \mathrm{a}$ & 56.65 \\
\hline $800+400$ & 16.32 & $30.85 \mathrm{ab}$ & $56.68 \mathrm{abc}$ & $68.92 \mathrm{a}$ & $74.88 \mathrm{a}$ & $60.83 a$ & 56.77 \\
\hline $800+800$ & 16.55 & $28.43 b$ & $46.15 \mathrm{c}$ & $76.38 \mathrm{~b}$ & $61.21 \mathrm{~b}$ & $51.82 b$ & 52.22 \\
\hline $\mathrm{SEM}^{2}$ & 0.65 & 1.90 & 4.55 & 7.91 & 11.24 & 13.27 & 2.79 \\
\hline P-value & 0.24 & $<0.0001$ & $<0.01$ & $<0.01$ & $<0.01$ & $<0.05$ & 0.54 \\
\hline
\end{tabular}

${ }^{1}$ Mean values for average daily gain (current BW - initial weight/Days (0-7, 0-39); current BW - previous BW - initial weight/days (7-14, 14-21, 21-28, 28-35, 35-39) in the same column followed by different letters are significantly different $(\mathrm{P} \leq 0.05)$. Abrupt changes were observed from day 35 to 39 because the chicks were fed for four days.

${ }^{2}$ Pooled standard error of least squares means. 
However, in this investigation ADG was affected from 14 to 39 days, in which $400+0$ resulted in the maximum ADG, and the minimum was found with $800+800$ (Table 7). These effects could mean that MOO thymol and carvacrol could act as growth promoters and improve digestibility, balance the microbial ecosystem of the gut, and stimulate endogenous secretion of digestive enzymes (Williams and Losa, 2001; Hernandez et al., 2004; Ocak et al., 2008). Thus, these results and the results obtained by Hong et al. (2012) suggest that the Mexican oregano oil can be considered a natural growth promoter, and evidence indicates that the MOO plant extracts (thymol, carvacrol) could have intrinsic biological activity in the broiler physiology and metabolism.

\section{Conclusions}

Mexican oregano oil supplementation in diets for chickens affects their weight, water consumption, feed intake, feed efficiency, and average daily gain. Mexican oregano oil can be used as a supplement in the diet to improve broiler production.

\section{References}

Adil, S.; Banday, T.; Ahmad Bhat, G.; Salahuddin, M.; Raquib, M. and Shanaz, S. 2011. Response of broiler chicken to dietary supplementation of organic acids. Journal of Central European Agriculture 12:498-508.

Alali, W. Q.; Hofacre, C. L.; Mathis, G. F. and Faltys, G. 2013. Effect of essential oil compound on shedding and colonization of Salmonella enterica serovar Heidelberg in broilers. Poultry Science 92:836-841.

Alçiçek, A.; Bozkurt, M. and Çabuk, M. 2004. The effect of a mixture of herbal essential oils, an organic acid or a probiotic on broiler performance. South African Society for Animal Science 34:217-222.

Arcila-Lozano, C. C.; Loarca-Piña, G.; Lecona-Uribe, S. and González de Mejía, E. 2004. El orégano: Propiedades, composición y actividad biológica de sus componentes. Archivos Latinoamericanos de Nutrición 54:100-111.

Avila-Sosa, R.; Gastélum-Franco, M. G.; Camacho-Dávila, A.; Torres-Muñoz, J. V. and Nevárez-Moorillón, G. V. 2010. Extracts of Mexican oregano (Lippia berlandieri Schauer) with antioxidant and antimicrobial activity. Food and Bioprocess Technology $3: 434-440$

Bampidis, V. A.; Christodoulou,V.; Florou-Paneri, P.; Christaki, E.; Chatzopoulou, P. S.; Tsiligianni, T. and Spais, A. B. 2005. Effect of dietary dried oregano leaves on growth performance, carcase characteristics and serum cholesterol of female early maturing turkeys. British Poultry Science 46:595-601.

Basmacioğlu, H.; Tokuşoğlu, Ö. and Ergül, M. 2004. The effect of oregano and rosemary essential oils or alpha-tocopheryl acetate on performance and lipid oxidation of meat enriched with n-3 PUFA's in broilers. South African Society for Animal Science 34:197-210.

Botsoglou, N. A.; Florou-Paneri, P.; Christaki, E.; Fletouris, D. J. and Spais, A. B. 2002. Effect of dietary oregano essential oil on performance of chickens and on iron-induced lipid oxidation of breast, thigh and abdominal fat tissues. British Poultry Science 43:223-230.

Bozkurt, M.; Küçükyılmaz, K.; Çatlı, A. U. and Çınar, M. 2009. Effect of dietary mannan oligosaccharide with or without oregano essential oil and hop extract supplementation on the performance and slaughter characteristics of male broilers. South African Society for Animal Science 39:223-232.

Brenes, A. and Roura, E. 2010. Essential oils in poultry nutrition: Main effects and modes of action. Animal Feed Science and Technology 158:1-14.

Castanon, J. I. 2007. History of the use of antibiotics as growth promoters in European poultry feeds. Poultry Science 86:2466-2471.

Cross, D. E.; McDevitt, R. M.; Hillman, K. and Acamovic, T. 2007. The effect of herbs and their associated essential oils on performance, dietary digestibility and gut microflora in chickens from 7 to 28 days of age. British Poultry Science 48:496-506.

Cho, J. H.; Kim, I. H. and Kim, I. J. 2014. Effects of phytogenic feed additive on growth performance, digestibility, blood metabolites, intestinal microbiota, meat color and relative organ weight after oral challenge with clostridium perfringens in broilers. Livestock Science 160:82-88.

Demir, E.; Sarica, S.; Özcan, M. A. and Suiçmez, M. 2003. The use of natural feed additives as alternatives for an antibiotic growth promoter in broiler diets. British Poultry Science 44:44-45.

Dorman, H. J. D. and Deans, S. G. 2000. Antimicrobial agents from plants: antibacterial activity of plant volatile oils. Journal of Applied Microbiology 88:308-316.

Dunford, N. T. and Silva, V. R. 2005. Effect of water stress on plant growth and thymol and carvacrol concentrations in Mexican oregano grown under controlled conditions. Journal of Applied Horticulture 7:20-22.

Dušan, F.; Sabol, M.; Katarína, D. and Dobroslava, B. 2006. Essential oils their antimicrobial activity against Escherichia coli and effect on intestinal cell viability. Toxicology In Vitro 20:1435-1445.

El-Ghany, W. A. A. and Ismail, M. 2013. Tackling of experimental colisepticaemia in broiler chickens using phytobiotic essential oils and antibiotic alone or in combination. Iranian Journal of Veterinary Research 15:110-115.

Giannenas, I.; Papaneophytou, C. P.; Tsalie, E.; Pappas, I.; Triantafillou, E.; Tontis, D. and Kontopidis, G. A. 2014. Dietary supplementation of benzoic acid and essential oil compounds affects buffering capacity of the feeds, performance of turkey poults and their antioxidant status, $\mathrm{pH}$ in the digestive tract, intestinal microbiota and morphology. Asian Australasian Journal of Animal Sciences 27:225-236.

Gopi, M.; Karthik, K.; Manjunathachar, H. V.; Tamilmahan, P.; Kesavan, M.; Dashprakash, M.; Balaraju, B. L. and Purushothaman, M. R. 2013. Essential oils as a feed additive in poultry nutrition. Advances in Animal and Veterinary Science 2:1-7.

Hernandez, F.; Madrid, J.; García, V.; Orengo, J. and Megías, M. D. 2004. Influence of two plant extracts on broilers performance, digestibility, and digestive organ size. Poultry Science 83:169-174.

Hong, J. C.; Steiner, T.; Aufy, A. and Lien, T. F. 2012. Effects of supplemental essential oil on growth performance, lipid metabolites and immunity, intestinal characteristics, microbiota and carcass traits in broilers. Livestock Science 137:219-225.

INEGI - Instituto Nacional de Estadística y Geografía e Informatica. 2013. Mexico en cifras: Información Nacional por Entidad Federativa y Municipios. Available at: <www3.inegi.org.mx/ sistemas/mexicocifras/default.aspx.> Accessed on: Dec. 14, 2013.

Jamroz, D.; Orda, J.; Kamel, C.; Wiliczkiewicz, A.; Wertelecki, T. and Skorupinska, J. 2003. The influence of phytogenic extracts on performance, nutrient digestibility, carcass characteristics and gut microbial status in broiler chickens. Journal of Animal and Feed Sciences 12:583-596. 
Kamel, C. 2001. Tracing modes of action and the roles of plant extracts in non-ruminants. p.135-150. In: Recent advances in animal nutrition. 5th ed. Garnsworthy, P. C. and Wiseman, J., eds. Nottingham University Press, Nottingham, UK.

Khan, R. U.; Naz, S.; Nikousefat, Z.; Tufarelli, V. and Laudadio, V. 2012. Thymus vulgaris: alternative to antibiotics in poultry feed. World's Poultry Science Journal 68:401-408.

Kintzios, S. E. 2002. Profile of the multifaceted prince of the herbs. p.3-8. In: Oregano: the genera Origanum and Lippia. 1st ed. Kintzios, S. E., ed. Taylor \& Francis Inc., London, UK.

Kırkpınar, F.; Ünlü, H. B. and Özdemir, G. 2011. Effects of oregano and garlic essential oils on performance, carcase, organ and blood characteristics and intestinal microflora of broilers. Livestock Science 137:219-225.

Kirkpinar, F.; Ünlü, H. B.; Serdaroğlu, M. and Turp, G. Y. 2014. Effects of dietary oregano and garlic essential oils on carcass characteristics, meat composition, colour, $\mathrm{pH}$ and sensory quality of broiler meat. British Poultry Science 55:157-166.

Küçükyılmaz, K.; Bozkurt, M.; Çınar, M.; Çatlı, A. U.; Bintaş, E. and Erkek, R. 2014. The effects of an organic rearing system and dietary supplementation of an essential oil mixture on performance and meat yield of slow-growing broilers in two seasons. South African Journal of Animal Science 44:360-370.

Lee, K. W.; Everts, H.; Kappert, H. J.; Yeom, K. H. and Beynen, A. C. 2003. Dietary carvacrol lowers body weight gain but improves feed conversion in female broiler chickens. The Journal of Applied Poultry Research 12:394-399.

Manning, L.; Chadd, S. A. and Baines, R. N. 2007. Key health and welfare indicators for broiler production. World's Poultry Science Journal 63:46-62.

Najafi, P. and Torki, M. 2010. Performance, blood metabolites and immunocompetence of broiler chicks fed diets included essential oils of medicinal herbs. Journal of Animal and Veterinary Advances 9:1164-1168

NOM-062-ZOO-1999. 1999. Norma Oficial Mexicana, especificaciones tecnicas para la produccion, cuidado y uso de animales de laboratorio. Available at: <http://www.economianoms.gob.mx/noms/consultasAction.do.> Accessed on: Dec. 10, 2013.

NRC - National Research Council. 1994. Nutritient requirements of poultry. 9th ed. National Academy Press, Washington, DC.

Ocak, N.; Erener, G.; Burak, F. A.; Sungu, M.; Altop, A. and Ozmen, A. 2008. Performance of broilers fed diets supplemented with dry peppermint (Mentha piperita L.) or thyme (Thymus vulgaris L.) leaves as growth promoter source. Czech Journal of Animal Science 53:169-175.

Ortega-Nieblas, M.; Robles-Burgueño, R.; Acedo-Félix, E.; González-León, A.; Morales-Trejo, A. and Vázquez-Moreno, L. 2011. Chemical composition and antimicrobial activity of oregano (Lippia palmeri S. Wats) essential oil. Revista Fitotecnia Mexicana 34:11-17.

Rivero-Cruz, I.; Duarte, G.; Navarrete, A.; Bye, R.; Linares, E. and Mata, R. 2011. Chemical composition and antimicrobial and spasmolytic properties of Poliomintha longiflora and Lippia graveolens essential oils. Journal of Food Science 76:C309-C317.

Roofchaee, A.; Irani M.; Ebrahimzadeh, M. A. and Akbari, M. R. 2011. Effect of dietary oregano (Origanum vulgare L.) essential oil on growth performance, cecal microflora and serum antioxidant activity of broiler chickens. African Journal of Biotechnology 10:6177-6183

Sugiharto, S. 2014. Role of nutraceuticals in gut health and growth performance of poultry. Journal of the Saudi Society of Agricultural Sciences, <http://dx.doi.org/10.1016/ j.jssas.2014.06.001>. Accessed on: Dec. 10, 2014.

Silva, V. R. and Dunford, N. T. 2005. Bioactive components of Mexican oregano oil as affected by moisture and plant maturity. Journal of Essential Oil Research 17:668-671.

Symeon, G. K.; Zintilas, C.; Ayoutanti, A.; Bizelis, L. A. and Deligeorgis, S. G. 2009. Effect of dietary oregano essential oil supplementation for an extensive fattening period on growth performance and breast meat quality of female medium-growing broilers. Canadian Journal of Animal Science 89:331-334.

Symeon, G. K.; Zintilas, C.; Demitris, N.; Bizelis, L. A. and Deligeorgis, S. G. 2010. Effect of oregano essential oil dietary supplementation on the feeding and drinking behavior as well as the activity of broilers. International Journal of Poultry Science. 9:401-405.

Williams, P. and Losa, R. 2001. The use of essential oils and their compounds in poultry nutrition. World Poultry 17:14-15.

Windisch, W.; Shedle, K. and Kroismayr, A. 2008. Use of phytogenic products as feed additives for swine and poultry. Journal of Animal Science 86:E140-E148.

Zhang, K. Y.; Yan, F.; Keen, C. A. and Waldroup, P. W. 2005. Evaluation of microencapsulated essential oils and organic acids in diets for broiler chickens. International Journal of Poultry Science 4:612-619. 